\title{
NARRATIVAS MITOLÓGICAS E O PAPEL DA MULHER NA CONSTITUIÇÃO DA NOBREZA PORTUGUESA ATRAVÉS DO LIVRO DE LINHAGENS DO CONDE D. PEDRO
}

\author{
Mythological Narratives and the role of women in the \\ constitution of the portuguese nobility through count $D$. \\ Pedro's book of lineages.
}

\author{
Prof. Dra. Neila Matias de Souza \\ Doutora em História Social/Idade Média \\ Docente de História do IFMA \\ Instituto Federal do Maranhão \\ neila.matias@ifma.edu.br \\ ORCID: https://orcid.org/0000-0002-7289-7107
}

Recebido em: 20/09/2019

Aprovado em: 13/04/2020

\begin{abstract}
Resumo : Uma das peculiaridades do Livro de Linhagens do Conde D. Pedro é exatamente o fato de ele não ser exclusivamente uma genealogia. Esta característica por si só faz desta espécie de "crônica da memória nobre medieva" de Portugal uma das fontes mais ricas e interessantes no que diz respeito ao conhecimento da aristocracia. O livro contém narrativas diversas de cunho variados, desde narrativas históricas, passando por anedotas e narrativas de fundo mítico. Estas últimas revelam-se de fundamental importância para compreender as estratégias e recursos utilizados pela nobreza para afirmar o seu poder. Em sua maioria, são textos curtos, mas embebidos de simbolismos, como não poderia deixar de ser, pelas suas constituições internas, que tendem a explicar a origem de uma linhagem de renome. Estas histórias não são exclusivas da nobreza portuguesa, as de fundo mítico então parecem reportar a outras congêneres que circulavam em grande parte da Europa, compondo um fundo cultural comum. São páginas sobre famílias de toda a Península Ibérica, galegas, castelhanas, navarras e portuguesas. Pretendemos aqui analisar como essas narrativas, através do papel da mulher, construíram uma legitimidade de fundo mítico para a aristocracia.
\end{abstract}

Palavras-chave: Mulher - Nobreza - Linhagens - Melusina - Aristocracia.

Abstract: One of the peculiarities of Count D. Pedro's Book of Lineages is precisely that it is not only a genealogy. This feature alone makes this kind of "chronicle of medieval noble memory" of Portugal one of the richest and most interesting sources with regard to the knowledge of the aristocracy. The book contains diverse narratives of varying nature, from historical narratives to anecdotes and mythical ones. The latter are capital to the understanding strategies and resources used by the nobility to assert their power. For the most part, they are short texts, but full of symbolism, of course, by their internal constitutions, which tend to explain the origin of a renowned lineage. These stories are not unique to the Portuguese nobility, the mythical ones then seem to report to other counterparts that circulated in much of Europe, composing a common cultural background. There are pages about families from all over the Iberian Peninsula, Galician, Castilian, Navarras and Portuguese. We intend here to analyze how these narratives, through the role of women, built a mythical background legitimacy for the aristocracy.

Key-words: Woman - Nobility - Lineages - Melusine - Aristocracy. 


\section{Introdução}

O Livro de Linhagens do Conde D. Pedro é a terceira, última e mais completa compilação das origens da nobreza da Espanha. Segundo José Mattoso, o "Livro de Linhagens do Conde D. Pedro é talvez a mais célebre fonte histórica medieval portuguesa. Fr. Francisco Brandão considerava-a 'a escrita de maior utilidade que temos em Espanha"” (MATTOSO, 1980, p.07). A obra apresenta significativas peculiaridades, pois, ao contrário dos dois livros anteriores dedicados ao assunto, o texto do Conde é recheado de narrativas de teor variado que abordam questões mitológicas, fundacionais, heroicas, anedóticas, religiosas e tantas outras.

Os primeiros livros sobre a aristocracia da Península Ibérica são de origem anônima ou pouco conhecidas, intitulados Livro Velho e Livro do Deão. Ao LV atribuise a datação de meados de 1270, embora José Mattoso mantenha discordâncias reivindicando uma datação mais tardia, por volta de 1282, "atendendo à época em que viveram a maioria dos nobres mais recentes que nele figuram" (MATTOSO, 1980, p. 47). Desta primeira genealogia restou apenas um fragmento bastante curto com nove páginas reunidas na Portugaliae Monumenta Historica ${ }^{l}$. O que foi conservado guarda, contudo, o essencial acerca da questão: o Prólogo, com as informações respeitantes ao âmbito da obra e às intenções do autor. A autoria do $L V$ gira em torno de figuras religiosas sob o comando de uma das grandes famílias da época. A família da Maia, através de seu representante por linha feminina, Gil Martins de Riba de Vizela, teria encomendado o serviço de redação da obra a um clérigo ou monge do mosteiro de Santo Tirso. Já o Livro do Deão se resume também a um fragmento, porém em melhor estado de conservação, já que mantém em suas páginas aproximadamente dois terços das linhagens enumeradas em seu prólogo. Deve ter sido redigido antes de 1343, mas não muito anteriormente a esta data, uma vez que os indivíduos que nele aparecem viveram durante o fim do reinado de D. Dinis ou princípio do de Afonso IV. Sua datação pode ser restringida aos limites cronológicos dos anos de 1337 a 1343, já que nele é citado o desbarato de Barcarrota, um episódio das guerras com Castela que ocorreu em 1337. "Dado que não se menciona o casamento de D. Pedro I com D. Constança Manuel, talvez seja possível aproximar as datas de 1337-1340, pois o casamento deu-se por procuração, em 1336, e pessoalmente, em 1340" (MATTOSO, 1980, p. 48). Para alguns 
autores, o $L D$ teria sido uma primeira versão da obra composta pelo Conde D. Pedro, que viria a ser o Livro de Linhagens.

O Livro de Linhagens do Conde D. Pedro, cuja autoria foi confirmada pelo estudo de dois importantes filólogos, Lindley Cintra e Diego Catalán Menéndez Pidal, constitui a terceira manifestação do interesse "historiográfico" de Portugal pelas origens de sua nobreza. Reconhecida a sua autoria, embora suas refundições sejam objeto de grandes debates acerca de quem as escreveu, é possível fixar o período entre 1325 a 1340 como o da reunião de todo o material necessário para a primeira redação, completada, então, entre 1340 e 1344. Diego Catalán e Lindley Cintra, com suas rigorosas análises, estabeleceram essa datação para a produção da obra. O texto com que atualmente temos contato é uma versão refundida duplamente, primeiramente em 1360-1365 e, posteriormente, em 1380-1383.

Os dois manuscritos que deram origem ao texto veiculado atualmente é o fragmento da Ajuda, constante no Scriptores sob o título de Livro III das Linhagens, cuja narrativa principal é dedicada à batalha do Salado. O manuscrito completo alojado na Torre do Tombo deu a base para a edição dos Scriptores. Esses dois manuscritos, na verdade, pertencem a um mesmo texto, dividido em dois e separando algumas narrativas.

[...] recordemos ainda que deve ter havido pelo menos outra coleção de genealogias com um caráter semelhante ao das duas primeiras e cuja existência foi deduzida por Herculano das referências a um livro de linhagens diferente do Conde, citado por Damião de Gois, ainda inédito, e que certamente terá conservado vestígios de obras medievais. O mesmo acontecerá, talvez, com o anônimo livro de linhagens do século XVI, publicado por Antonio Machado de Faria em 1956 ou com outras obras semelhantes do mesmo século. (MATTOSO, 1980, p. 48).

Estes três livros de linhagens remanescentes foram publicados por Alexandre Herculano nos Portugalie Monumenta Histórica, volume Scriptores, constituindo sua seção mais ampla, o que engloba cerca de dois terços do grandioso volume. Ao compararmos toda a extensão dos Livros de Linhagens com o restante da produção "historiográfica" portuguesa anterior ao final do século XIV, ou seja, aos textos dos Scriptores e à Crônica Geral de 1344, observamos que os livros de linhagens configuram quase a metade do material. Toda esta extensão e volume de informações acerca das linhagens da Península Ibérica contrasta bastante com as genealogias 
medievais europeias, caracterizadas por uma comum narrativa "seca", curta e estereotipada, restringindo-se à enumeração dos membros das famílias e seus respectivos parentescos. Outro aspecto importante relativo àquelas genealogias, que Mattoso destaca, é que, por serem "bastante concentradas no tempo, pois estes textos abrangem menos de um século, no máximo de 1270 a 1350, tal produção revela, portanto, um súbito e amplo interesse pela genealogia na classe nobre portuguesa" (MATTOSO, 1980, p. 47).

Os livros de linhagens portugueses, especialmente aquele do Conde D. Pedro, não são simplesmente genealogias com enumeração encadeada e crua de antepassados e descendentes por linha direta e indireta, com suas linhas verticais e horizontais de parentesco. Sua especificidade decorre do fato de também abordarem questões envolvendo as relações da nobreza com a realeza, e suas problemáticas internas. Assim, o Livro de Linhagens do Conde D. Pedro não deve ser classificado meramente como uma genealogia. O $L V$ e o $L D$ já apresentavam traços cronísticos, mas relativos a pessoas bem determinadas, especialmente informações voltadas a melhor caracterização de algum personagem, ou em alguns casos de relatos relativamente extensos com cunho lendário, como a ilustre lenda do Rei Ramiro, monarca que teria dado origem aos bons fidalgos de Portugal e Castela. A narrativa sobre o rei cristão que se enamorou de uma moura já estava presente, portanto, no mais antigo livro de linhagens. Mas, em linhas gerais, os dois primeiros livros mantêm-se estritamente no campo genealógico, figurando claramente como os primeiros exemplares dedicados a informar sobre as origens da nobreza. É somente no Nobiliário do Conde D. Pedro que as notícias, relatos e narrativas diversas ganham volume substancial, transformando este livro num exemplar híbrido de crônica e genealogia recheado de informações capazes de esclarecer a estruturação da sociedade a que se refere, em especial no que diz respeito aos seus membros situados no topo da escala social. É, pois, um exemplo único de material variado e consistente, um rico manancial para o conhecimento da nobreza.

\section{Melusina: a mulher sereia fundadora de linhagens}

Um dos relatos míticos fundadores de grandes linhagens é sobre uma mulher, meio humana - meio sereia ou dragão, ou ainda meio serpente, a mulher sereia, mulher 
dragão, mulher serpente, Melusina. Le Goff é autor de um estudo sobre o alcance e significado desta lenda para a Europa, em especial para a França e a família dos Lusignan. Em artigo publicado como capitulo de livro $^{2}$ cuja primeira edição data de 1979, mas tem redação inicial de 1971, embora se referindo a várias regiões do velho continente e até mesmo a contos africanos e indígenas, Jacques Le Goff, curiosamente, não reporta a presença da lenda no $L L$. Esta ausência talvez possa ser explicada porque apenas no ano seguinte sairia o estudo vigoroso de José Mattoso sobre a nobreza portuguesa; ou porque, de fato, a Península Ibérica sempre esteve à parte de uma medievalística europeia pela qual foi influenciada e cujos modelos adotou. Ou ainda, como sugere Ana Maria Machado:

A Dama do pé de cabra medieval não é abordada com frequência nos estudos sobre «a fada do desenvolvimento econômico» da Idade Média (Le Goff, "Melusina", 306), talvez por desconhecimento de sua existência. Embora o estatuto desta dama da floresta, como desbravadora, não seja tão marcante quanto em outras versões medievais, o simbolismo de suas exigências finais mostra bem a importância de sua função provedora. (MACHADO, 2011, p. 2)

Le Goff analisa o significado da mulher-serpente para a sociedade da época, bem como as implicações da sua lenda na configuração das famílias que a utilizaram para divulgar e garantir uma origem de prestígio que transcendesse a realidade puramente humana. Segundo o historiador francês, não podemos simplesmente nos contentar com o significado cristão atribuído a esta lenda, bastante óbvio, e também escamoteador da realidade social. "Se os usos e costumes dos demônios súcubos explicam, aos olhos dos clérigos medievais, a natureza e a história de Melusina, o mesmo não pode suceder conosco" (LE GOFF, 1993, p. 305).

Se abordarmos agora os problemas de interpretação, devemos, antes de tudo, notar que os autores medievais deram uma explicação muito clara do que Melusina era para eles. Ela representava para todos um demônio súcubo, uma fada assimilada aos anjos perdidos pelo pecado. É semipessoa, semianimal e das suas cópulas com um mortal nascem filhos excepcionais, dotados de dons físicos (beleza para as raparigas, força para os homens), porém tarados ou infelizes. Alguns explicam também a razão destes casamentos. A serpente [a mulher], condenada por qualquer pecado a sofrer no corpo duma serpente, procura a união com um homem, o único ser capaz de a arrancar à sua eternidade infeliz e de permitir-lhe morrer de morte natural e usufruir depois de uma outra vida venturosa. (LE GOFF, 1993, p. 304). 
Ora, as narrativas melusinianas são anteriores ao cristianismo, fazem parte de um fundo cultural antiquíssimo que percorre diferentes regiões do globo com algumas modificações, mas preservando sempre seu elemento estrutural, qual seja: uma mulher não-humana que só pode chegar à condição de humanidade pela intervenção de um homem. Guardemos esta informação.

Em meio europeu, consta do século XII uma narrativa que gira em torno de uma mulher não-humana. Teria sido escrita por Gautier Map, clérigo da corte real da Inglaterra, entre 1181 e 1193. A história, contida no De nugis cirialium, remete ao casamento de um jovem, "Henno dos Dentes Grandes", com uma criatura estranha. Na floresta - há um "mistério ambivalente da floresta, que gera, ao mesmo tempo, angústia e serenidade, opressão e simpatia" (CHEVALIER \& GHEERBRANT, 1991, p. 439) ${ }^{3}$ Henno encontra uma jovem extremamente bela chorando devido a um naufrágio que a impediu de chegar ao reino de França, com cujo rei deveria se casar. Encantado com a beleza da jovem desconhecida, Henno apaixona-se e casa-se com ela, que lhe dá muitos filhos. No entanto, a mãe de Henno desconfia da jovem que evita as missas e a água benta. "Intrigada, a sogra abre um buraco na parede do quarto da nora e surpreende-a a tomar banho, sob a forma de um dragão (draco), e readquirir depois a sua forma humana, após haver cortado, em pedacinhos, com os dentes, um manto novo" (LE GOFF, 1993, p. 290). A esposa, após ser espargida com água benta, desaparece pelos ares soltando um grande urro. A descendência de Henno e de sua esposa-serpente seria ainda numerosa ao tempo do autor do relato.

Em uma outra narrativa, Ralmond, contada por Gervais de Tilbury, o senhor do Château-Rousset encontra uma bela dama, muito bem vestida, perto de um rio. Os dois acabam casando-se sob a condição de que o marido nunca a olhasse tomar banho, caso contrário perderia toda a riqueza e prosperidade que ela lhe proporcionaria. Mas, um dia o esposo a observa tomando banho, e ela se transforma em serpente, sumindo nas águas para sempre. Durante a noite as amas a ouvem, quando ela volta para ver os filhos. Aqui também, como na história de Henno, a mulher não é nomeada.

A literatura sobre as mulheres-serpente que de fato vigorou e alcançou o sucesso foi apropriada pela família nobre da França, dos Lusignan. "[...]. Nos fins do século XII, o conto do homem casado com a mulher-serpente corre em várias regiões: na 
Normandia, na Provença, nas áreas dos Langres ou na Saintonge" (LE GOFF, 1993, p. 299). Muitas famílias e seus descendentes “[...] procuram apropriar-se do conto, para com ele fazerem a sua lenda. Foram os Lusignan quem o conseguiu" (LE GOFF, 1993, p. 299). Assim, temos o Romance de Melusina ou A Nobre História de Lusignan, escrita em prosa por João d' Arras para o duque de Berry e sua irmã Maria, no século XIV, entre os anos de 1387 a 1394. Uma outra obra, em verso, nomeada $O$ Romance de Lusignan ou de Pasthenay, ou simplesmente, Melusina, foi executada, entre 1401 e 1405, pelo livreiro parisiense Couldrette ${ }^{4}$. Independentemente do êxito desta família ligado ao nome de Melusina, a questão mais importante a se perguntar, segundo Le Goff, é: "[...] porquê, a partir do século XII, o interesse de certas personagens e determinados meios (cavaleiros, clérigos, "povo") pelas Melusinas?" (LE GOFF, 1993, p. 300). Essa pergunta também nos guiará em nossa abordagem da "origem" da família dos Haros de Biscaya no Livro de Linhagens.

Eis do que trata a história de Melusina ${ }^{5}$. Durante uma caçada a um javali, Raimondin, filho do conde de Forez e sobrinho do conde de Poitiers, mata seu tio por acidente. Numa fonte ("Fonte da Sede" ou "Fonte Fada") encontra três mulheres belíssimas, entre as quais Melusina, que o consola e promete-lhe torná-lo um senhor poderoso se aceitasse contrair matrimônio com ela. Raimondim aceita, mas Melusina faz-lhe jurar que jamais tentará vê-la aos sábados. Os dois vivem em grande prosperidade; Melusina desbrava terras e constrói cidades e castelos, começando pelo castelo de Lusignan. Tiveram uma grande prole, dez filhos ao todo, que fazem bons casamentos e tornam-se reis em várias regiões. Mas, todos os filhos são marcados por algum defeito físico no rosto, e o sexto, Geoffroy, possui um grande dente.

Após a visita de um irmão que lhe instiga com boatos sobre sua mulher, que passaria o sábado todo com um amante ou, por ser fada, tiraria este dia em penitência, Raimondim, tomado por ciúme e cólera, faz um buraco na porta para observar Melusina no banho e surpreende-se ao ver sua mulher sob a forma de sereia. Raimondim mantémse calado sobre o que viu, assim como Melusina, que age como se nada tivesse ocorrido. Porém, quando Geoffroy queima um mosteiro, Raimondim, levado pela ira refere-se à mulher como uma serpente falsa, cujos feitos não passavam de ilusão, dizendo que nenhum dos seus herdeiros se salvaria. Melusina, então, foge pela janela 
sob a forma de serpente alada. Volta à noite para cuidar dos filhos menores, mas não é vista, sinalizando sua presença com lamentos, "o grito da fada".

Le Goff explica que a natureza de Melusina é revelada através de sua função na lenda. Ela seria uma espécie de fada da fecundidade, garantindo ao esposo força e saúde e cumulando-o de prosperidade material através dos arroteamentos. "As clareiras abrem-se-lhe debaixo dos pés, as florestas transformam-se em campos lavrados” (LE GOFF, 1993, p. 305), desenvolvendo também atividade criadora por meio da construção de castelos-fortes a cidades: "Tanto ou mais que arroteadora, Melusina torna-se construtora. Semeia, no seu caminho, nas suas constantes deslocações, castelos-fortes e cidades que bastas vezes constrói com as próprias mãos, à frente dos trabalhadores" (LE GOFF, 1993, p. 306). Finalmente, onde sua fecundidade se mostra mais gritante, Melusina povoa. Mesmo que nem todas as variantes da lenda apresentem um grande número de filhos, o primeiro sinal de riqueza que ela proporciona é a descendência.

\footnotetext{
Por pouco precavidos que estejamos em relação ao historicismo, seria sem dúvida querer deixar de fugir a verdade se recusássemos ver aqui o lado histórico de Melusina ligada à conjuntura econômica: arroteamentos e construções, arroteamento e depois construção. Melusina é a fada do desenvolvimento econômico medieval. (LE GOFF, 1993, p. 306).
}

Produzir uma descendência constituía um fator primordial para manter a família e perpetuar o nome e, principalmente, o poder sobre os demais, garantindo a manutenção dos privilégios da nobreza.

Analisando vários contos e lendas que giram em torno do silêncio feminino e guardam nítidas semelhanças com as lendas melusinianas, Isabel Cardigos mapeia a amplitude destas narrativas em regiões como o norte da África, em algumas das histórias de As Mil e uma Noites, e modernamente em textos da cultura israelense da década de 1960. “A riqueza do seu tecido de associações simbólicas leva-nos a crer que se trata duma forma madura e erudita duma lenda bem enraizada no imaginário popular" (CARDIGOS, 2006, p. 91).

Um outro texto medieval, A Ninfa da Sicília, de Geoffroy de Auxerre (séc. XII) possui um caráter edificante. Escrito por um clérigo e contido em meio a sermões, pretende, uma vez mais pela mão da Igreja, demonizar a mulher e condenar o casamento com estas criaturas distanciadas das práticas cristãs. 
Enquanto tomava banho no mar com os amigos, um jovem agarra uma mulher pelos cabelos pensando ser um de seus companheiros. Ela o seguiu docilmente até a margem e ao ser perguntada sobre quem era não respondeu porque não falava; o jovem acaba levando-a para casa e os dois se casam. Ela dá à luz um menino, que não permitia que lhe tirassem do colo. Convencido por um amigo que suspeitava da mudez daquela mulher, o marido finge um movimento de matar o filho com a espada e a mulher então fala, condenando tão vil ato. Afirma que a partir dali, para infelicidade do marido que a obrigou a falar, não mais terá sua esposa tão dedicada e toda a felicidade que ela the daria se continuasse mantida em seu silêncio. A mulher foge levando o filho e os dois não mais são vistos.

Em uma lenda da tradição oral maiorquina, conhecida como La Ninfa, um velho que vive sozinho se dá conta, em determinado momento, de que sempre que chegava em casa tudo estava arrumado e todos os animais alimentados. Para tentar descobrir quem lhe fazia tais coisas, esconde-se e vê sair de um poço uma ninfa; após interpelá-la, propõe-lhe casamento. A ninfa aceita a proposta, com a condição de que ele jamais a trate por ninfa. Casaram-se e tiveram dois filhos, um menino e uma menina. O transcurso de suas vidas ia bem até que um dia ele observa que ela havia arrancado todas as flores no lugar das ervas daninhas. Mesmo lhe explicando que só tinha feito aquilo por conta de uma geada que se aproximava e que acabaria queimando tudo, ele ficou irritado e a chamou de ninfa. Ela pegou então cada filho e voltou ao poço, de onde nunca mais saiu.

Para a autora, a lenda de Dona Marinha parece pertencer muito mais aos contos maravilhosos e traz semelhanças com um conto de fora da Europa, o "Julnar do Mar", de As Mil e Uma Noites. Porque nenhuma de suas cem concubinas lhe dá um descendente um velho rei vive desolado. Acaba comprando a um mercador mais uma mulher, lindíssima. Mas esta mulher não fala absolutamente nada e permanece indiferente a todas as demonstrações de amor e respeito que o rei tem por ela. $\mathrm{O}$ silêncio só é rompido quando a mulher, em consideração ao marido por respeitar seu silêncio, revela estar esperando um filho. Esclarece ser filha do rei do mar e que por ter se zangado com o irmão saíra para a terra. Finalmente, a família do mar é chamada ao castelo por ela e todos se reconciliam. 
Partindo da análise de Le Goff e Cardigos sobre mulheres melusinianas e o interdito de seus silêncios, como podemos analisar a lenda da Dama do Pé de Cabra no que diz respeito à nossa proposta investigativa de mulheres que deram origem a linhagens? Como caracterizar uma linhagem não só puramente masculinizada, embora esse seja seu sinal mais evidente?

Em duas das narrativas analisadas por Cardigos, La Ninfa da Sicília e La Ninfa, temos mulheres que, após os maridos quebrarem o juramento feito a elas, acabam fugindo com os filhos, assim como nas narrativas sobre a Melusina, embora guardem diferenças expressivas de significado, de acordo com a autora. Mas, diferentemente da Melusina, as mulheres destes dois contos não sofrem uma transformação em mulherserpente/ mulher-dragão/ mulher-sereia, ainda que também sejam encontradas na água. Também não há qualquer informação sobre terem dado continuidade a uma linhagem, suas descendências parecem ter se esvaído em meio a fluidez de seus desaparecimentos. Tanto Melusina como a Dama do Pé de Cabra originam linhagens. Cabe aqui um questionamento: as narrativas míticas mobilizadas por algumas famílias, mesmo que para comprovar um ancestral antigo para além do domínio humano, justificavam também o papel da mulher naquela sociedade como portadora do sobrenatural e mãe, acima de qualquer coisa?

\section{A Dama do Pé de Cabra e a Linhagem dos Haros - Uma narrativa mitológica} no Livro de Linhagens

A história sobre da Dama do Pé de Cabra está contida no Título IX do LL, intitulado De como os de Biscaia, por nam terem senhor, tomarom por senhor Froom, irmão d'el rei de Inglaterra, que i veo teer com um seu filho, e como dele descenderam os de Bizcaia.

O fundador da família Biscaia é D. Froom, acima referido no título, mas é seu bisneto, Dom Diego Lopez, que dará continuidade a sua linhagem como membro mais lembrado, seja pelos seus feitos, seja pelo seu casamento com a Dama do Pé de Cabra. Fizemos a análise a partir da divisão da narrativa em dois momentos: o encontro com a mulher na floresta e a sua partida após o homem violar o pacto acordado entre os dois. Segue a primeira parte da narrativa, em que o nobre encontra a bela dama. 
Este Dom Diego Lopez era mui boo monteiro e estando ûu dia em sa armada atendendo quando verria o porco, ouviu cantar muita alta voz ûa molher em cima de ûa pena. E el foi pera la e vio-a seer mui fermosa e mui bem vestida, e namorou-se logo dela mui fortemente, e preguntou-lhe quem era. E ela lhe disse que era ûa molher de muito alto linhagem. E el lhe disse que pois era molher d'alto linhagem que casaria com ela se ela quisesse, ca ele era senhor daquela terra toda. E ela lhe disse que o faria se lhe prometesse que nunca se santificasse. E ele lho outorgou, e ela foi-se logo com ele. E esta dona era mui fermosa e mui bem feita em todo seu corpo, salvando que havia ûu pee forcado como pee de cabra. E viverom gram tempo, e houverom dous filhos (LL, 1980, pp.138-139).

O primeiro aspecto que salta aos olhos nesta passagem é a valorização da linhagem e o poderio de D. Diego Lopez, representado pela sua armada de cavaleiros, sendo ele mesmo um cavaleiro muito bom. Ao que tudo indica, ele era senhor de uma vasta propriedade, englobando não só a área de habitação senhorial como uma área de reserva florestal destinada à caça do senhor com seus cavaleiros e vassalos. É exatamente neste espaço natural que encontrará uma mulher que carrega em seu corpo uma marca animalesca.

A mulher é simplesmente referida como "uma mulher"; não é nomeada, não que isso seja específico desta situação, pois muitas mulheres ao longo do $L L$ não são nomeadas. O curioso é que, quando indagada por D. Diego Lopez sobre quem era ela, não revela o seu nome, mas dá a informação mais importante para um nobre de tão alta estirpe: "E ela lhe disse que era ûa molher de muito alto linhagem". A beleza é um sinal destacado duas vezes, primeiro no momento do encontro e, portanto, do encantamento do senhor por ela, e depois para realçar seu defeito, afirmando-se que a formosura só não era completa pelo pé em forma de "pé de cabra". A mulher estava muito bem vestida, logo não seria camponesa, o que é confirmado com sua resposta ao declarar-se de origem abastada. Certamente deveria estar usando uma cota (vestido). "Talhada em fazenda, veludo, seda etc., a cota possuía em geral mangas estreitas e compridas e costumava ser aberta nas costas até abaixo da cintura" (MARQUES, 1987, p. 51). Todos estes caracteres formam o principal elemento distintivo, cuja condição é primordial para D. Diego casar-se com ela: a origem nobre. "E el lhe disse que pois era molher d'alto linhagem que casaria com ela se ela quisesse, ca ele era senhor daquela terra toda". É sabido que a nobreza contraía casamento dentro de sua classe social, garantindo o domínio sobre os demais e ampliando suas condições materiais. 
Nas outras narrativas vistas anteriormente, analisadas por Le Goff e Cardigos, ainda que em algumas não houvesse claramente alusão à posição social ocupada pela mulher encontrada pelo homem que seria seu futuro marido, todas fazem menção à beleza da mulher e aos ricos trajes que usam, além da função mais importante que todas aquelas mulheres exercem: garantem a continuidade da família através dos filhos que dão ao marido e muitas favorecem até mesmo sua prosperidade material.

Há um dado bastante importante nesta narrativa: a mulher tem consciência do lugar que sua classe social ocupa naquela sociedade e, o mais importante, tem consciência de sua própria classe social. Fazer parte de uma alta linhagem indica a existência de outras linhagens não tão nobres, e até mesmo pressupõe a ideia de linhagem para aquela sociedade. Linhagem, aqui e em outras passagens do $L L$, é um conceito muito mais amplo do que o de um pequeno grupo formado pela parentela mais próxima em linha horizontal, abrangendo ancestrais longínquos que levaram uma determinada família ao nível mais alto do ordenamento social.

No entanto, há um interdito para que o casamento se realize em todas as narrativas, e também na lenda da dama: o homem deve prometer nunca se persignar diante da esposa. Ele o promete e o casamento é consumado, gerando um casal de filhos: Enheguez Guerra e uma filha que não é nomeada. É bastante claro que o impedimento imposto pela mulher é um elemento cristão, o que caracteriza a grande antiguidade de tal lenda naquela região e remete ao processo de cristianização de contos e lendas pagãs.

\footnotetext{
Constata-se já neste interdito o vestígio de uma ruptura e de uma incompatibilidade entre o mundo fantástico das fadas, dominado por uma relação mágica com a natureza e com os elementos, e o mundo cristão [..]. Todavia, o interdito da Dama do Pé de Cabra não deixa de ter pertinência. De facto, o mundo sobrenatural das fadas só poderá sobreviver à margem do cristianismo, daí que a imposição de o cavaleiro se afastar dessa mundividência acabe por isolá-lo do mundo real. (SOARES, 2011, p. 14).
}

A mulher de Diego Lopez traz no corpo uma marca de sua natureza extra-humana: um pé forcado tal como a pata de uma cabra. O pé animalesco "revela a sua pertença ao mundo natural e pagão. Aproxima-a dos Faunos, divindades silvestres e protetoras, propiciadoras da fecundidade e da prosperidade da terra" (SOARES, 2011, p. 13). Há também outros sinais de afastamento da humanidade - embora não sejam tão claros 
quanto os de Melusina, pois ela não se transmuta em serpente -, como o fato de ter sido encontrada em cima de um penedo e, especialmente, o de ter sido notada por Diego Lopez pela sua voz. Qual uma sereia, ela seduz o nobre com o seu canto, enfeitiça-o com seus dotes físicos e, principalmente, com o seu pertencimento a uma classe superior. Passemos ao segundo momento da história, quando já casados e com filhos o marido quebra a promessa feita à esposa:

E quando comiam de suum dom Diego Lopez e sa molher, assentava el a par de si o filho, e ela assentava a par de si a filha da outra parte. E ûu dia, foi ele a seu monte e matou um porco mui grande e trouxe-o pera sa casa e pose-o ante si u siia comendo com sa molher e com seus filhos. E lançarom ûu osso da mesa, e veerom a pelejar ûu alão e ûa podenga sobr'ele em tal maneira que a podenga travou ao alão em a garganta e matou-o. E dom Diego Lopez, quando esto vio, teve-o por milagre, e sinou-se e disse: "Santa Maria val, quem vio nunca tal cousa!". E sa molher, quando o vio assi sinar, lançou mão na filha e no filho, e dom Diego Lopez travou do filho e nom lho quis deixar filhar. E ela recudio com a filha por ûa freesta do paaço, e foi-se para as montanhas, em guisa que a nom virom mais, nem a filha. (LL, v. II/1, p. 139).

Nesta segunda parte da narrativa, temos um primeiro desenrolar da história de D. Diego Lopez com sua mulher, já que ela não desaparece completamente do transcurso dos acontecimentos de sua vida, como veremos adiante. Aqui, há muitos elementos significantes que põem em xeque a diferença relacional da vida dos dois. Ao contrário da passagem anterior, esta é carregada de simbolismos e metáforas. Mas, antes, atentemos para o fato de a filha ficar sempre próxima à mãe e o filho, ao pai. Esta relação não pode ser reduzida simplesmente a uma questão de afinidade. O filho homem era preparado pelo pai para a vida adulta, iniciado por ele nas artes da guerra, nos hábitos que caracterizavam a nobreza, como a caça, em especial o filho homem, o primogênito, que dava continuidade à família e seguia com o nome da linhagem. Esta talvez tenha sido a razão para o pai segurar firmemente o filho, impedindo assim que a mãe o levasse.

É impossível não observar, mais uma vez, a evidência do estatuto social desta família. A alimentação medieval era muito pobre em vitaminas, baseava-se essencialmente no consumo de cereais, carnes, peixes e vinho. Havia uma carência muito grande de vitaminas A, D e C. Obviamente, estes dados atingiam níveis espantosos quando observados entre a população campesina. O caso da família aqui 
analisada é bem diferente tendo-se em vista a posição que ocupava e as condições de vida de que desfrutava. Sua principal fonte de alimentação constituía-se de carne, especialmente de caça. "A base da alimentação por excelência era a carne. Ao lado das carnes de matadouro ou carnes gordas - vaca, porco, carneiro, cabrito [...] - consumiase largamente caça e criação" (MARQUES, 1987, p. 8). D. Diego Lopez voltava novamente de uma caçada, agora com um porco capturado, e próximo à mesa, enquanto jantava com a mulher e filhos, havia também um casal de cães. Nada mais representativo da aristocracia do que cães ao redor da mesa de jantar. E quando o marido quebra o acordo com a esposa fazendo o sinal da cruz, ela foge por uma fresta no paço. Ora, para uma família tão ricamente caracterizada nada mais coerente do que habitar um palácio. Trata-se, portanto, de um rico-homem, membro de uma família importante o suficiente para ter sua história retratada pelo Conde D. Pedro no Livro de Linhagens.

A caracterização da aristocracia no ambiente descrito na passagem acima se torna ainda mais significativa ao percebermos o embate existente entre dois espaços, um binômio bem clássico em textos deste tipo, ali situados. Há uma firme relação de opostos complementares: civilização e barbárie. Vejamos: a cena é de uma alimentação à mesa, um jantar, em que os membros da família estão reunidos. Ora, este ato é uma representação do caráter civilizatório que toma a aristocracia da época; ao contrário, temos o contraste com a chegada do marido cujo fruto da caçada, um porco, é colocado diante dos seus. A caça e o banquete posto; a carne crua e a alimento cozido. Não bastasse isso, pensemos no ambiente em que se desenrola os acontecimentos e o seu desenlace: todos estão no palácio, numa área reservada à alimentação, com uma mesa e assentos; no outro extremo aparece o monte, de onde D. Diego Lopes trouxe a caça e, finalmente, as montanhas, para onde sua mulher foge com a filha. Temos aqui então um espaço urbanizado, habitado, civilizado - o paço; e um outro espaço - as montanhas domínio da natureza, incivilizado, hostil à presença humana. É para lá que a Dama do Pé de Cabra retorna, pois foi na natureza que aconteceu seu encontro com o homem, senhor das terras, das armas e da cultura. Também não passa despercebida a luta entre os dois cães - pelo osso lançado da mesa - sendo vencida pela fêmea que acaba por matar o macho 6 . 


\begin{abstract}
O episódio da disputa pelo mesmo osso entre o alão, cão utilizado na caça grossa, e a podenga, animal usado para a caça do coelho, simboliza a luta entre o mundo real e o sobrenatural, entre o mortal e a Fada. O encanto tinha de ser quebrado, pois D. Diego não podia viver eternamente no Outro Mundo, era necessário que a Fada recuasse ao seu ambiente natural, agora que a sua missão fundadora fora cumprida. (SOARES, 2011, p. 14).
\end{abstract}

Foi diante desta circunstancia que aparenta ser incompreensível para o senhor que ele comete a imprudência de benzer-se, fazendo o sinal da cruz e rompendo, desta forma, o acordo estabelecido com a esposa para que ambos se casassem. No entanto, a transgressão ao pacto já é uma condição de partida em relações que envolvam um humano e uma fada. A transgressão é inevitável e mesmo necessária para a continuidade e sobreposição do humano sobre o mundo incompreensível das fadas.

A metodologia proposta por Goldmann e sua síntese tão bem elaborada por Ciro Flamarion Cardoso parece-nos essencial para problematizarmos o sentido desta narrativa $^{7}$.

1. Situação Inicial: Um nobre senhor de Biscaia, Dom Diego Lopes, neto de Dom Froom, vai ao monte com sua armada de cavaleiros.

2. Perturbação da Situação Inicial: Dom Diego Lopes, um cavaleiro muito bom de montaria, estando com sua armada, vê um porco.

3. Desequilíbrio, crise: Em plena caçada o nobre ouve o canto muito alto da voz de uma mulher de cima de um penedo.

4. Intervenção na crise: D. Diego dirige-se até aonde estava a mulher, vê toda sua beleza e como estava bem vestida. O senhor de Biscaia logo se apaixona muito fortemente por ela e pergunta-lhe quem era. A resposta é bastante satisfatória, pois ela afirma pertencer a uma linhagem muito distinta. $\mathrm{O}$ cavaleiro então afirma que se casaria com ela por ser uma mulher de alta linhagem e ele senhor de toda aquela terra. Ela aceita casar-se com D. Diego com a condição de que ele prometesse nunca se persignar.

5. Novo equilibrio: Sob a promessa feita, os dois se casam e vivem um longo tempo, e desta relação frutifica um casal de filhos. A senhora era extremamente formosa e muito bem-feita de corpo, exceto por um detalhe: possuía um de seus pés forcado, como um "pé de cabra".

$\mathrm{Na}$ segunda parte da narrativa faremos uma nova análise estrutural quando, portanto, surge um novo equilíbrio. Teremos o desdobramento desta união entre um humano e uma mulher sobrenatural, e as consequências advindas de um conflito que mais cedo ou mais tarde iria se manifestar. Vejamos, então, a outra sequência de análise da narrativa. 
1. Situação Inicial: O senhor sempre comia com o filho perto de si e a mulher tinha a filha junto a ela.

2. Perturbação da situação inicial: Um dia o marido sai para caçar e mata um porco muito grande.

3. Desequilíbrio ou crise: D. Diego Lopez traz para casa o porco e o coloca aonde estavam comendo sua mulher e filhos. É lançado um osso para o casal de cães da família que estava junto à mesa. Os animais brigam entre si e a fêmea mata o macho, ferindo-o na garganta.

4. Intervenção na crise: $\mathrm{O}$ nobre senhor fica admirado diante do acontecido e, tomando aquilo por milagre, faz o sinal da cruz, recomendando-se à mãe de Deus: "Santa Maria val, quem viu nunca tal cousa".

5. Novo equilibrio: Sua mulher, após o marido ter quebrado a promessa, tenta fugir com os dois filhos, mas só consegue levar a filha. Elas fogem por uma fresta do palácio para as montanhas e nunca mais são vistas.

A estrutura da lenda da Dama do Pé de Cabra também pode ser analisada da seguinte forma:

1. A lenda principia com um encontro entre o cavaleiro e uma mulher sobrenatural, já que estava numa pena, que de alguma forma o seduz com sua linda voz, sua beleza e sua origem social.

2. Parte-se para um pacto proposto pela dama: ela só aceitaria o casamento se o homem prometesse jamais se persignar. Aqui o pacto é explícito, é a condição para que haja o casamento entre os dois.

3. Acontece a união entre o homem e a mulher "encantada".

4. Algum elemento exterior, seja um parente ou amigo, neste caso é uma situação, desencadeia a transgressão do pacto. Em todo caso, inevitavelmente, acontece a transgressão.

5. Com o rompimento do acordo, a consequência é sempre o desaparecimento da mulher sobrenatural. 
Algumas observações acerca desta lenda são necessárias: é impossível não associarmos a narrativa sobre a Dama do Pé de Cabra com as histórias sobre a Melusina. Elas têm um fundo comum, embora guardem algumas diferenças, como veremos adiante. A lenda da dama constitui sem dúvidas um texto melusiniano. Num contexto mais generalizado, cabe a pergunta: por que algumas famílias possuem narrativas míticas sobre a sua origem, ou membro importante de sua linhagem? No caso da lenda da Dama do Pé de Cabra, a narrativa mítica não está ligada ao fundador da linhagem, mas a seu bisneto. Aliás, sobre o filho de D. Froom, fundador da linhagem de Biscaia, não há maiores informações, a não ser o nome da esposa e sua respectiva família de origem. O pai de Diego Lopez, neto de D. Froom, lutou contra os mouros e dele saiu o então senhor de Biscaia, que se casou com uma mulher sobrenatural. Sobre a mãe de Diego Lopez nada sabemos. Neste sentido, a história dos Biscaia contada no Livro de Linhagens parece de fato começar com o bisneto, Diego Lopez. É ele quem dará origem a uma geração de homens invariavelmente ligados a guerras contra os mouros. Voltaremos, adiante, mais detidamente às origens desta família com a narrativa de fundação da linhagem a partir de D. Froom.

A Dama do Pé de Cabra, ao contrário de Melusina, não promete prosperidade material ao futuro marido e, embora ela afirme pertencer a uma linhagem muito nobre, nenhuma informação sobre a sua família é fornecida. Nesta lenda, a função também parece ser a de uma mulher fertilizadora que (não tanto quanto Melusina - mãe de uma enorme prole) propicia ao marido um casal de filhos, garantindo assim a continuidade da linhagem. Se sua função é a de prosperidade material, harmonia, caça abundante em seus domínios, talvez o seja ainda mais de prestígio social. Ora, tanto a dama quanto o cavaleiro que a encontrou partilham o mesmo estatuto social, não havendo, portanto, qualquer surpresa quanto ao futuro compromisso que virá do encontro entre membros de uma mesma origem social. A dama, por pertencer a uma alta linhagem, através do casamento com o senhor de Biscaia manteria as relações dentro de uma mesma classe social, unindo duas linhagens de grande prestígio. O casamento, portanto, é legítimo! Independentemente de sua natureza animalesca e do embate advindo dela com a natureza humana de seu marido, a união dos dois funda e justifica a procedência superior dos senhores daquela terra. 
Já que tomamos como base a lenda de Melusina, um quadro comparativo exemplifica bem suas diferenças e semelhanças:

\begin{tabular}{|c|c|c|}
\hline \multicolumn{2}{|r|}{ DIFERENÇAS } & \multirow[t]{2}{*}{ SEMELHANÇAS } \\
\hline Dama do Pé de Cabra & Melusina & \\
\hline $\begin{array}{c}\text { Encontrada na floresta } \\
\text { sobre um penedo. }\end{array}$ & Encontrada numa fonte. & Extrema beleza \\
\hline $\begin{array}{l}\text { Recebe a proposta de } \\
\text { casamento do humano. }\end{array}$ & $\begin{array}{l}\text { Propõe casamento ao humano } \\
\text { prometendo-lhe prosperidade. }\end{array}$ & Pacto \\
\hline $\begin{array}{c}\text { A marca de sua } \\
\text { sobrenaturalidade, o pé } \\
\text { forcado com o de uma } \\
\text { cabra, não é um segredo. }\end{array}$ & $\begin{array}{c}\text { O caráter sobrenatural de } \\
\text { Melusina aparece aos sábados } \\
\text { durante o banho. }\end{array}$ & Caráter animalesco \\
\hline $\begin{array}{l}\text { O pacto é quebrado pelo } \\
\text { marido por um gesto. }\end{array}$ & $\begin{array}{l}\text { A transgressão do pacto pelo } \\
\text { marido deve-se à } \\
\text { exteriorização pela fala da } \\
\text { condição sobrenatural da } \\
\text { mulher. }\end{array}$ & Interdito \\
\hline $\begin{array}{l}\text { A mulher não é mais vista, } \\
\text { no entanto irá intervir num } \\
\text { episódio da história do } \\
\text { marido. }\end{array}$ & $\begin{array}{l}\text { A fada desaparece } \\
\text { completamente. }\end{array}$ & Amor maternal \\
\hline
\end{tabular}

A Dama do Pé de Cabra também não se transforma em serpente, dragão ou sereia, tal como nas histórias melusinianas. Mas ela guarda, à semelhança das sereias, o domínio de uma bela voz que seduz o humano. A estrutura da lenda poderia ser sintetizada no seguinte esquema: 


\title{
ENCONTRO - PACTO - INTERDITO - TRANSGRESSÃO - DESAPARECIMENTO
}

O mais interessante é que a presença desta mulher na vida de Diego Lopez não termina com a sua fuga para as montanhas. Há um desdobramento na história deste homem em que sua antiga esposa será fundamental. A saída de D. Diego Lopez em busca de aventuras tão longínquas como a que empreende contra os mouros é uma forma de reforçar seu poder senhorial, alargando seus domínios territoriais e ampliando o prestígio de sua linhagem. A legitimação do seu nome viria também da sua participação na "Reconquista". "Procura-se enaltecer neste membro dos Haros a sua capacidade guerreira, o seu espírito empreendedor, que não se contenta com o legado dos antepassados e que procura estender o seu poder e a sua influência para além dos confins do território ancestral legitimamente herdado". (SOARES, 2011, p. 15).

\begin{abstract}
Depois, a cabo de tempo, foi este dom Diego Lopez a fazer mal aos Mouros, e prenderom-no e levarom-no pera Toledo preso. E a seu filho Enheguez Guerra pesava muito de sa prisom, e veo falar com os da terra per que maneira o poderia haver fora da prisom. E eles disserom que nom sabiam maneira por que o podessem haver salvando se fosse aas montanhas e achasse sa madre; e que ela lhe daria como o tirasse. E el foi alá soo, em cima de seu cavalo, e achou-a em cima de ûa pena. E ela lhe disse: "Filho, Enheguez Guerra, vem a mim ca bem sei eu ao que vêes". E el foi pera ela e ela lhe disse: "Vêes a preguntar como tirarás teu padre da prisom". Entom chamou ûu cavalo que andava solto pelo monte, que havia nome Pardalo, e chamou-o per seu nome. E ela meteo ûu freo ao cavalo, que tinha, e disse-lhe que nom fezesse força pelo desselarnem polo desenfrear nem por lhe dar de comer nem de bever nem de ferrar; e disse-lhe que este cavalo lhe duraria em toda sa vida, e que nunca entraria em lide que nom encesse dele. E disse-lhe que cavalgasse em ele e que o poria em Toledo, ante a porta $u$ jazia seu padre, logo esse dia, e que ante a porta u o cavalo o posesse, que ali decesse e que acharia seu padre estar em ûu curral, e que o filhasse pela mão e fezesse que queria falar com ele, e que o fosse tirando contra a porta u estava o cavalo. E des que ali fosse, que cavalgasse em o cavalo e que posesse seu padre ante si, e que ante noite seria em sa terra com seu padre. E assim o foi. (LL, pp.139-140).
\end{abstract}

O primeiro aspecto a destacar é a consulta que o filho de Diego Lopez faz aos da terra. Quando se tratava de uma decisão importante a tomar que envolvesse toda uma região, e ainda por cima com ideais caros ao cristianismo como a luta contra os mouros, uma decisão conjunta não poderia ser evitada. O episódio parece revelar que as consultas deviam ser uma prática corrente entre aqueles homens. Suas opiniões 
encerram também um discurso de autoridade perante o jovem herdeiro do senhorio de Bizcaia. Ora, o poder de um senhor não é simplesmente medido por sua força militar ou pela riqueza de suas terras. O poder senhorial é primordialmente expresso pela sua capacidade de reconhecimento, que envolve entre outras coisas aconselhar-se com os seus. E embora não tivessem a solução para o problema, apresentaram uma alternativa capaz de resolvê-lo. Cumpriram, portanto, um dos papeis destinados aos vassalos. O pacto feudal renovava-se assim a cada vez que as circunstâncias demandavam a participação efetiva de senhores e vassalos exercendo as prerrogativas de seus direitos e deveres.

Ao partir ao encontro de sua mãe, é inevitável observarmos a semelhança desta situação com a que envolveu seu pai. Novamente, a dama se encontra em um penhasco, e sabe exatamente que seu filho viria e o que procurava. Em seu habitat natural, longe da civilização e de todo o interdito que ela propiciava, a Dama do Pé de Cabra restabeleceu seu caráter maravilhoso e seus poderes sobrenaturais, podendo assim ajudar Enheguez Guerra a combater os mouros e resgatar o seu pai. Aqui, o maravilhoso mais uma vez se faz presente, e a situação também se assemelha à anterior, quando a dama de bom grado e sem receber nada em troca (lembremos que ela afirmou a dom Diego Lopes ser uma mulher de muito alta linhagem) aceitou-se casar com o nobre senhor $^{8}$. Para seu filho, sem exigir qualquer contrapartida, ela também oferecerá seus dons. "Ora, é justamente o caso dessas Damas Abundância que oferecem seus favores sem que seja preciso solicitá-los; basta-lhes reconhecer a coragem do beneficiário, confirmada, em nosso caso aqui, seja pela caça, seja pela bravura de seus antecedentes". (MACHADO, 2011, p. 4). A função da dama como provedora é, a partir de então, renovada como protetora. É a partir dos seus favores que a linhagem dos Haros se perpetuará no tempo e são eles que garantirão seu sucesso por várias gerações, até que a obrigação para a senhora, agora transformada em serpente, seja rompida e o caos se instale.

Novamente um pacto é feito, agora com o filho. "No início, a função da Dama associa-se, sobretudo, à fecundidade reprodutora e, após a ruptura diabólica, ela continua a assegurar a proteção da linhagem, ajudando o filho a liberar o pai" (MACHADO, 2011, p. 5). A prosperidade da família dos Haros há de se manter. E, para além da manutenção deste poder, promove-se a sua renovação e ampliação na figura de 
Enheguez Guerra. Ora, a mãe havia dito que ele jamais perderia qualquer contenda em que entrasse: "e disse-lhe que este cavalo lhe duraria em toda sa vida, e que nunca entraria em lide que nom encesse dele". Portanto, o filho honrará o nome da família através dos feitos da guerra, uma das principais formas de garantir o prestigio de um nobre e perpetuar sua linhagem.

A introdução de um elemento mágico, representado pelo cavalo Pardalo, é uma constante na morfologia dos contos maravilhosos. Este elemento visa, muitas vezes, possibilitar um novo desfecho para os acontecimentos, coroando assim a trajetória do herói. O caráter fantástico do animal é bastante evidenciado não só pela inexistência de um transcurso temporal de toda a ação, como também por constituir ele próprio uma espécie de arma: "E ela meteo ûu freo ao cavalo, que tinha, e disse-lhe que nom fezesse força pelo desselarnem polo desenfrear nem por lhe dar de comer nem de bever nem de ferrar; e disse-lhe que este cavalo lhe duraria em toda sa vida, e que nunca entraria em lide que nom encesse dele" (LL, v.1, p. 140). Pardalo não é um cavalo comum, ele não precisa se alimentar. Também não é o cavaleiro que o conduz, é a montaria que guia o cavaleiro. E, finalmente, os dois formam um todo orgânico garantidor das vitórias militares e unidos por toda uma vida de conquistas. Enheguez Guerra toma o lugar do pai. De agora em diante, o próprio Diego Lopez o outorga, deixando todas as suas terras e bens para ele. Este lugar também é simbólico. É o filho da Dama do Pé de Cabra quem recebe um apoio mágico, e é também ele que, desbravando por suas atividades militares, aumentará o patrimônio de sua linhagem. Algo também notável para a construção de sua história familiar é o fato de ter libertado seu pai dos mouros, do inimigo cristão, embora não tenha havido um confronto direto neste processo de resgate de Diego Lopez. Como toda narrativa destinada a glorificar uma família, a dos Haros apoia-se em aspectos míticos para sobrepor e justificar sua ascendência superior, seja perante outros senhores locais, seja para se contrapor ao rei de Castela que disputa toda aquela região ${ }^{9}$.

O desenlace da narrativa mítica da família dos Haros não podia deixar de apresentar novamente elementos fantásticos e mais um interdito a ser cumprido. A trajetória dos Haros fica assim marcada pelo sucesso ou fracasso em função dos rigores que uma presença sobrenatural poderia propiciar a uma linhagem. 
E depois, a cabo de tempo, morreo dom Diego Lopez, e ficou a terra a seu filho, dom Enheguez Guerra. E algûus há em Bizcaia que disserom e dizem hoje em dia que sa madre // de Enheguez Guerra que este é o coovro (?) de Bizcaia. E cada que i é o senhor de Bizcaia em ûa aldea que chamam Vusturio todolos deventres daas vacas que matam em sa casa, todolos manda poer em ûa peça fora da aldeã, em ûa pena; e pela menhãa nom acham i nada, e dizem que se o nom fezesse assi que algûu nojo receberia del em esse dia e neessa noite em algûu escudeiro de sa casa, ou em algûa cousa de que se muito doesse. E esto sempre o assi passarom os senhores de Bizcaia ataa morte de dom Joham, o Torto. E algûus o quiserom provar de o nom fazer assi, e acharom-se mal. E mais dizem hoje em dia i, que jaz com algûas molheres i nas aldeas, ainda que nom queiram, e vem a elas em figura d'escudeiro, e todas aquelas com que jaz tornam escooradas. (LL, p. 140).

Se a punição por outro pacto não-cristão não veio de imediato, impondo-se ao filho, a desgraça não deixará de cair sobre os senhores de Bizcaia ao longo de algumas gerações. "Após a sexta geração da família, a ordem foi desobedecida e a Dama - agora metamorfoseada em serpente para engolir sua refeição - traveste-se então em um escudeiro para deitar com as mulheres da cidade e sugar-lhes o sangue" (MACHADO, 2011, p. 13). Ao que parece, nenhuma aliança, seja ela mítica ou de outra natureza, é permanente e duradoura o suficiente para manter o domínio de uma linhagem sobre uma região.

O castigo imputado pela Dama é bastante simbólico, e recai exatamente sobre o que de mais caro pertencia a nobreza, embora representado por um escudeiro. Ora, o escudeiro aqui é o símbolo da guerra e do militarismo necessário para que uma família como a dos Haros perpetuasse seu poder. Se a penalidade era justamente imposta a um representante das armas, ela significava, como de fato ocorreu, o fim daquilo que constitui uma parte primordial do que é ser nobre. O fim da linhagem estava, portanto, vaticinado. A derrocada é dupla: os favores mágicos são perdidos e, consequentemente, todo o brilho que trazia, pois agora não é mais considerado como um sinal de prestígio e sim como uma maldição que levou ao fim toda uma geração. Além da suposta superioridade adquirida pelo elemento mágico, os senhores de Bizcaia perdem também seu poder material. Duplo desprezo. Dupla mancha. Fim duplo. A genealogia de uma família pode, então, facilmente alcançar o mais alto posto dentre todas as narrativas com a presença insubstituível e fundamental de um elemento magico. No entanto, este mesmo elemento é capaz de destruí-la, pondo fim à sua honra e ao seu nome no quadro de uma nobreza que buscava qualquer tipo de estratégia para chegar ao poder e manterse nele. 


\section{Considerações Finais}

É importante ressaltar que Enheguez Guerra assume o senhorio deixado pelo pai e, como bravo guerreiro já anunciado e previsto por sua mãe, vence muitas batalhas e aumenta o seu domínio sobre vastos territórios conquistados. A função desbravadora da dama, do modelo melusiniano, é então realizada pelo filho.

$\mathrm{Na}$ construção genealógica de uma linhagem, no caso especifico dos Haros, muitos outros caminhos poderiam ser tomados, outros cruzamentos vários poderiam ter sido estabelecidos. Sua genealogia, inclusive, poderia ter sido construída sem a presença de um elemento mágico. Mas é exatamente este elemento que faz com que uma família sem muito destaque junto a outros grupos nobres possa ser então notada. Até mesmo em relação aos relatos melusinianos, no plano da historicização, a Dama do Pé de Cabra apresenta inovações:

\footnotetext{
O grande desafio concerne justamente no estabelecimento de uma harmonia entre uma empresa nitidamente cristã - a cruzada contra os mouros - e as ações comandadas por uma fada que está sendo diabolizada. Quando percebemos que a libertação de Diogo Lopes do jugo muçulmano foi favorecida pelo intermédio de um objeto mágico oferecido pela Dama e que as condições que ela exige de Inigo Guerra prolongam o pacto maléfico, há algo de incompreensível na ajuda que ela traz a um cavaleiro cristão, sobretudo quando este está sob o poder dos mouros, logo, dos aliados da Dama-diabo e de sua corte. (MACHADO, 2011, p. 15).
}

A explicação para o auxílio da fada não pode reduzir-se a um amor maternal. As complexidades que permeiam a construção da narrativa desta linhagem vão além de um fio puramente amoroso, o que limitaria não só a história da família como a própria imagem da mulher-fada, que seria reduzida a um caráter singularmente humano. Para Ana Maria Machado, apoiada em Luís Krus, a função da Dama termina por consolidarse como proteica: "L. Krus interpreta o gesto benfazejo da Dama como um reforço dos poderes bélicos; indiferente à traição do passado, ela assegura as vitórias da linhagem, então representada pelo filho, Inigo Guerra" (MACHADO, 2011, p. 16). A linhagem dos Haros, portanto, é beneficiada por uma presença sobrenatural capaz de imputar a esta família não só a conquista de territórios e a garantia de uma geração para perpetuar o seu nome. A proteção, função proteica, para que tudo isso fosse possível, constituía-se como fundamental. 


\section{FONTE}

Livro de Linhagens do Conde D. Pedro. PORTUGALIAE MONUMENTA HISTORICA. Edição Crítica por José Mattoso, v. II/1. Publicações do II Centenário da Academia das Ciências. Lisboa: 1980.

\section{REFERÊNCIAS}

CARDIGOS, Isabel. "A Mudez de dona Marinha: lendas e contos em torno do silêncio da mulher". In: BELTRÁN, Rafael e HARO, Marta. El Cuento Folclórico en la literatura y en la tradición oral. PUV: Universitat de València, 2006.

CHEVALIER, Jean \& GHEERBRANT, Alain. Dicionário de Símbolos: mitos, sonhos, costumes, gestos, formas, figuras, cores, números. Rio de Janeiro: José Olympio, 1991

MACHADO, Ana Maria. "O maravilhoso e a poética da incerteza em A dama do pé-de cabra (da Idade Média ao século XXI)". In: O MARRARE, no 14, 2011, pp. 117. Disponível em: http://www.omarrare.uerj.br/numero14/pdf/tra traducao_de_Batalha_do_art_de_Ana_Maria_Machado.pdf, acessado em 01 de setembro de 2019 .

OLIVEIRA MARQUES, A.H. A Sociedade Medieval Portuguesa: aspectos $\boldsymbol{d a}$ vida cotidiana. Livraria Sá da Costa Editora: Lisboa, 1987.

SOARES, Ana Maria. "A Lenda da Dama do Pé de Cabra: do Livro de Linhagens do Conde D. Pedro de Barcelos a Alexandre Herculano”. In: LIMITE, No5, 2011, pp.730 .

LE GOFF, Jacques. Para Um Novo Conceito de Idade Média. Lisboa: Editorial Estampa, 1993.

MATTOSO, José. "Introdução". In: Livro de Linhagens do Conde D. Pedro. Portugaliae Monumenta Historica. Edição Crítica por José Mattoso, v. II/1. Publicações do II Centenário da Academia das Ciências. Lisboa: 1980.

MATtoso, José. A Nobreza Medieval Portuguesa: a família e o poder. Lisboa: Editorial Estampa, 1980.

\footnotetext{
${ }^{1}$ A Portugaliae Monumenta Historica pode ser acessada on-line através do sítio da Biblioteca Nacional de Portugal no seguinte link: http://purl.pt/12270

${ }^{2}$ Trata-se do livro intitulado Para um Novo Conceito de Idade Média, cujo capítulo é "Melusina Maternal e Arroteadora".

${ }^{3}$ A floresta é um topos, assim como o rio, nas lendas, contos e narrativas de cunho fantástico. A floresta em muitas culturas, celta, chinesa e japonesa, constituía um verdadeiro santuário, proporciona o poder através dos benefícios do céu garantidos pela chuva. Ela também é o símbolo da vida, intermediária que é entre o céu, através de sua copa, e a terra, por meio de suas raízes. Há também um "mistério ambivalente da floresta, que gera, ao mesmo tempo, angústia e serenidade, opressão e simpatia"., (p. 439). Veremos ao
} 
longo do capítulo em outras variações da lenda que ora a mulher-serpente, mulher-sereia se encontra numa floresta, ora num rio.

${ }^{4}$ Essas duas narrativas sobre Melusina são bastante ricas em detalhes, mais longas que as anteriores, e a história adquire o aspecto de romance. $\mathrm{O}$ resumo aqui apresentado consiste no essencial dos textos de João d'Arras e Couldrette muito semelhantes entre si, já que se especula que tenham partido de uma fonte comum. "Em certos pontos, o poema de Couldrette conservou elementos desprezados por Arras ou por este incompreendidos, tais como as maldiçoes agrárias pronunciadas por Melusina no momento em que desaparece". (LE GOFF,1993, p. 293).

${ }^{5}$ Tomamos como base o relato feito por Le Goff ao analisar o mito de Melusina.

${ }^{6}$ A presença dos cachorros junto à família, ao redor da mesa, é mais uma afirmação do domínio do homem sobre a natureza, domesticando-a, controlando-a, tomando-a para si tal qual D. Diego Lopez fez com sua esposa.

${ }^{7}$ A metodologia sugerida pelos autores envolve uma análise estrutural da narrativa por meio da poética estruturalista de Tzvetan Todorov levando em consideração os seguintes aspectos do texto: semânticos, verbais, figuras de linguagem e outros. De acordo com Todorov, um relato possui sequências narrativas divididas em cinco partes: 1) situação inicial; 2) perturbação da situação inicial; 3) crise ou desequilíbrio; 4) intervenção na crise; 5) novo equilíbrio.

${ }^{8}$ Embora a dama do pé de cabra tenha exigido do senhor que ele não se santificasse, pois esse era o interdito para que a união sobrenatural pudesse ser concretizada, não há qualquer transação material envolvendo este casamento, prática tão comum nos matrimônios intranobiliárquicos.

${ }^{9}$ A primeira parte da narrativa sobre a família dos Haros pode ser considerada como uma reação aos propósitos de dominação da realeza de Castela sobre aquela região. 